\title{
$\$$
}

NORDIC JOURNAL

of Science and Technology Studies

\section{Utopia Revisited. Towards a Carbon-Neutral Neighbourhood at Brøset}

Eli Støa, Stig Larssæther, Annemie Wyckmans, Fagbokforlaget, 2014

Av Lina Hopaneng Ingeborgrud

Utopia Revisited - Towards a Carbon-Neutral Neighbourhood at Broset er en tverrfaglig antologi som tar opp forskjellige aspekter ved planleggingsprosessen av den karbonnøytrale bydelen Brøset i Trondheim. Utopia Revisited er basert på forskningsprosjektet "Towards Carbon-neutral Settlements - Processes, Concept Development and Implementation", der samtlige av antologiens 18 forfattere har vært involvert. Artiklene i Utopia Revisited er derfor tett knyttet opp mot antologiforfatternes egne erfaringer rundt planleggingsprosessen for Brøset. Selve byggingen av Brøset har ikke startet, men leseren får innsikt i hvilke muligheter og hindringer forskerne og fagfolkene støtte på i prosjekt- og planleggingsperioden.

Ifølge redaktørene er den overordnede visjonen for Brøset å demonstrere hvordan nye bydeler kan planlegges i henhold til FNs togradersmål, og slik vise veien mot et karbonnøytralt samfunn. Artikkelforfatterne problematiserer at miljøvennlig byutvikling tradisjonelt har fokusert på utslippsreduksjoner knyttet til bygg og transport, og argumenterer i stedet for en holistisk tilnærming som involverer teknologiske, sosiale og kulturelle aspekter. Slik ser de for seg at Brøset kan fungere som et levende laboratorium for å teste ut nye verktøy, konsepter og teknologier, der mulige framtidige innbyggere involveres og engasjeres i planleggingsprosessen. Forfatterne argumenterer gjennomgående for at Brøset skiller seg fra tidligere områdeprosjekter ved å fokusere på livsstil, samt en bredere forståelse av bærekraftighet hos arkitekter og planleggere. Dette er antologiens hovedargument, og er ifølge redaktørene dens viktigste bidrag til framtidige byutviklingsprosjekt.

Utopia Revisited henvender seg til forskere, planleggere og forvaltere som er interessert i miljøvennlig by- og områdeutvikling, så vel til studenter som vil utforske muligheter og utfordringer i eget fagområde. Flertallet av forfatterne har bakgrunn innen byplanlegging, arkitektur og design, og fagfeltet spenner fra ingeniørfaglige til samfunnsfaglige disipliner. Artiklene er basert på både kvantitative og kvalitative undersøkelser; fra beregning av produksjon og utslipp fra sol, - vind- og bioenergi, til fokusgruppeintervjuer om framtidens bo- og levemåter. Særlig de kvalitative studiene lar leseren komme nærmere innpå deltakerne og prosessene.

Antologien har derfor noe å tilby de som er interesserte i samspillet mellom by, teknologi og mennesker, som en del STS-ere er. Larssæther trekker for eksempel fram aktørnettverksteori som et nyttig perspektiv for å forstå kompleksiteten i oversettelsen av klimakunnskap til planstrategier. STS-perspektivene er også sentrale hos Gansmo, som benytter Michel Callons translasjonsmodell for å vise hvordan miljøkunnskapen i prosjektet er et forhandlingsprodukt.

Forfatterne forklarer at de fire planleggingsteamene ASPLAN, CODE, COWI og SLA måtte beregne såkalte reboundeffekter for de kommende innbyggerne i Brøset. Reboundeffekten innebærer at en klimavennlig livsstil er økonomisk gunstig, men at oppsparte midler i mange tilfeller brukes på ikke-klimavennlige aktiviteter. Dette er derfor en av de største hindringene for å skape en miljøvennlig livsstil i et land med høy inntekt og forbruk, og ved å inkludere reboundeffekten ble teamene utfordret til å tenke nytt rundt miljøvennlig byutvikling. Støa og Larssæther påpeker dessuten at det er en risiko for at framtidens innbyggere vil domestisere omgivelsene på en annen måte enn arkitektene antar. Slik kritiserer de arkitektenes naivitet ved å tro at de kan 'fryse' visse livsstiler inn i materialer og form. Denne naiviteten trekkes fram som en mulig årsak til at tidligere miljøprosjekter har feilet. Derfor ble lokalbefolkningen i Trondheim invitert til dialog og diskusjon om framtidens bo- og levemåter i Brøset, og denne arbeidsformen trekkes fram som en av Brøset-prosessens innovative strategier. Wyckmans og Rolf Andre Bohne argumenterer for at design av bygninger og struktur i seg selv ikke er nok til å skape karbonnøytrale motstandsdyktige nabolag, og understreker at for å nå FNs togradersmål kreves særlig interaksjon mellom bygninger, energisystemer og livsstil.

Antologiens hoveddel, "Between planning and research", består av 13 kapitler der forfatterne diskuterer muligheter og utfordringer for Brøset, knyttet til teknologiske, økonomiske, sosiale og kulturelle faktorer. Hoveddelen preges av en felles grunnholdning om at miljøvennlige bydeler må planlegges i skjæringspunktet mellom det teknologiske, sosiale og estetiske, og det er denne holdningen som binder artiklene sammen og blir en av antologiens styrker. En annen styrke er at leseren får et bredt innsyn i planleggingsprosessen som helhet, i tillegg til de helt konkrete forslagene presentert av planleggingsteamene. Kapitlene er mer eller mindre tilfeldig strukturert, og dekker blant annet områder som energi i bygg, transport, brukerinvolvering, bærekraftig arkitektur og dialogarbeid. Det store tematiske spennet fører til at leseren raskt må omstille seg, både hva gjelder metode- og teoribruk, skrivestil og illustrasjonsbruk. Hver artikkel har sitt spesialfelt, og tverrfagligheten framstår slik sett mer flerfaglig. Enkelte av artiklene inneholder mange fagspesifikke forkortelser, som kan virke ekskluderende for lesere utenfor det gitte fagfeltet. Det oppleves 
noe paradoksalt at antologien om Brøset - et prosjekt der tverrfaglig samarbeid stadig trekkes fram som nøkkelen til gode prosesser - forblir flerfaglig i selve strukturen. En annen svakhet ved antologiens struktur er at det blir en del repetisjoner; for eksempel beskrives de fire Brøset-teamene opptil flere ganger.

Det tette samarbeidet mellom forskere og planleggere er gjennomgående en sentral tematikk, og i konklusjonen argumenterer redaktørene for at samarbeidet har resultert i ny kunnskap om planleggingsprosesser. Ifølge Larssæther har prosjektet bidratt til å sette utfordringer knyttet til miljøvennlig planlegging på den politiske agendaen, samt økt kunnskapen om miljøproblemer i Trondheim. Dermed presenteres Brøset først og fremst som et kunnskapsutviklingsprosjekt mellom forskere og planleggere, og redaktørene ønsker at antologien skal være en inspirasjonskilde for de som er involvert i slike prosjekter. Likevel trekker redaktørene fram muligheten for at Brøset ender opp som nok et overambisiøst urealisert miljøprosjekt. Områdeeierne har ikke kommet til enighet om interesser og ansvarsområder, hvilket har ført til mange forsinkelser i realiseringen av prosjektet.
Dette viser at det er lettere å lage rapporter og planer enn å oppnå faktiske endringer, hvilket forblir noe underkommunisert fram til konklusjonen. Her forklarer redaktørene at svært få prosjekter har klart å oversette klimakunnskap til meningsfull handling på lokalt nivå. Videre påpeker de at det å utvikle vitenskapelig valid kunnskap, og det å få ting til å skje, er to ulike ansvarsområder. Dette er viktige refleksjoner, og blir stående som Brøset-prosjektets store utfordring.

På samme måte som samtlige forfattere av Utopia Revisited uttrykker engasjement og interesse for å realisere Brøset, blir også leseren utålmodig på prosjektet vegne: hvem tar det første spadetaket? Hvordan planlegge og hvordan bygge et "Utopia»? Som tittelen Utopia Revisited tilsier er ikke Utopia nødvendigvis uoppnåelig, men bør i stedet, som det påpekes avslutningsvis, forstås som et konsept med andre kvaliteter enn dagens by- og landområder.

Lina Hopaneng Ingeborgrud is a PhD Candidate at the Department of Interdisciplinary Studies of Culture at the Norwegian University of Science and Technology. Her research focuses on environmental knowledge management in Norwegian local governments. 